\title{
Teaching About Sex and Gender in Neuroscience: More Than Meets the "XY"
}

\author{
Kathleen V. Casto*1, Elizabeth C. Leininger*2, and Taralyn Tan ${ }^{\star 3,4}$ \\ ${ }^{*}$ All authors contributed equally to this manuscript, and are listed alphabetically. \\ ${ }^{1}$ Division of Social Sciences, New College of Florida, Sarasota, FL 34243; '2Division of Natural Sciences New College of \\ Florida, Sarasota, FL 34243; ${ }^{3}$ Department of Neurobiology, Harvard Medical School, Boston, MA 02115; ${ }^{4}$ PhD Program in \\ Neuroscience, Harvard University, Cambridge, MA 02138.
}

Offering courses on the neuroscience of sex and gender can help support an inclusive curriculum in neuroscience. At the same time, developing and teaching such courses can be daunting to even the most enthusiastic educators, given the subject's complexities, nuances, and the difficult conversations that it invites. The authors of this article have all developed and taught such courses from different perspectives. Our aim is to provide educators with an overview of important conceptual topics as well as a comprehensive, but non-exhaustive, guide to resources for teaching about sex/gender in neuroscience based on our collective experience teaching courses on the topic. After defining vital terminology and briefly reviewing the biology of sex and sex determination, we describe some common topics within the field and contrast our current nuanced understandings from outdated misconceptions in the field. We review how (mis)representation of the neuroscience of sex/gender serves as a case study for how scientific results are communicated and disseminated. We consider how contextualization of sex/gender neuroscience research within a broader historical and societal framework can give students a wider perspective on the enterprise of science. Finally, we conclude with a brief discussion on how to choose learning goals for your course and implementation notes.

Key words: sex; gender; sex difference; LGBTQ; inclusive teaching; course design
Although courses about sex and gender are traditionally housed within Gender Studies or other social sciences and humanities areas, Neuroscience has become a key area for exploring and teaching the science behind sex/gender. Research on sex/gender differences in the brain and behavior has far-reaching repercussions both within and beyond the scientific community. With neuroscience training and educational programs on the rise and growing larger in their curriculum offerings, Sex/Gender and the Brain may very well be a core course for both teaching the fundamentals of neuroscience and using the biological underpinnings of sex to introduce students to complex social-societal-scientific discussions. In this way, such a course can also promote inclusion in neuroscience training programs by creating a space to discuss complex and often contentious topics that are relevant to students' lives. Students can apply their learning to future careers that intersect with gender such as research, healthcare, policy, and beyond.

A growing number of institutions require students to take courses that engage with issues of power, privilege and difference as part of their general education (e.g., "diverse perspectives" requirements), but on the whole the sciences lag behind non-science fields in offering courses that are inclusive of diversity (Laird and Engberg, 2011). As a human enterprise, science is shaped by societal norms and frames of reference that influence what sorts of questions are asked, why they are asked, and how they are answered at specific points in history (reviewed in Harrington, 2020).
Offering courses on sex/gender and the brain is one way to enhance diverse perspectives offerings in the sciences. Courses that are framed and listed as both neuroscience and gender studies are an effective way to engage an interdisciplinary student audience (e.g., Mead, 2009).

In addition to providing a valuable opportunity to discuss societal issues in the science classroom, case studies related to sex/gender and the brain are particularly wellsuited for students to practice essential scientific skills such as critical thinking, experimental design, and science communication. A wealth of case studies can be used to illustrate flawed experimental design, interpretation, and/or communication to the general public; some such case studies are described in the below sections.

\section{STARTING WITH TERMINOLOGY Defining Sex and Gender}

By convention, the term sex is used when making reference to biological components or systems of classification that are anatomical, histological, genetic, or hormonal $(\mathrm{NIH}$ and APA recommendations). Some use the term "biological sex" in an attempt to clarify this distinction. For example, the recent US 2020 Census question about sex of household members gave two options, "Male" or "Female". If a respondent were to click the corresponding "Help" link, the following statement was given, "Select one response to indicate the person's biological sex" (ironically unhelpful as well as ignorant). Biological sex is often conflated with sex assigned at birth or natal sex, the decision made by doctors 
and parents at or prior to a person's birth based usually on the appearance of external genitalia and sometimes, but rarely, corroborated by a karyotype. The assignment of sex based on external genitalia is problematic for several reasons, but specifically to the point here, it is based on a singular and potentially unreliable aspect of physiological sex anatomy. Thus, sex assigned at birth is an imperfect proxy for the numerous and potentially non-matching components of sex.

In apparent contrast to sex, gender is used when making reference to socio-cultural systems, which describe the ways in which sex interacts with culture, psychology, and history to produce gendered self-identity and performative acts (e.g., Hyde et al., 2018). The umbrella term of gender encompasses concepts such as gender identity, the perceptions of one's own gender and associated behavioral expressions; gender roles, norms, and/or expectations that are defined by societal rules and patterns; gender attributions, the characteristics or qualities of an individual imposed by gender roles; and gender relations, the power and resource distributions imposed by gender roles. Roughgarden (2013) offers a definition of gender that could apply to non-human animals, especially species that have different "types" of males or female that diverge in appearance and behavioral phenotype: "the appearance, behavior, and life history of a sexed body (p.27)." Notably, this definition best encapsulates gender expression rather than gender identity. In the animal literature, there is debate about when sex versus gender should be used to describe features of behavior and physiology (compare Clayton and Tannenbaum, 2016 and Holmes and Monks, 2019), and the two are sometimes inadvertently conflated (GarciaSifuentes and Maney, 2021).

As discussed in Cortes et al. (2019) and defined by Risman and Davis (2013), gender is also a social structure that inherently produces power and resource inequities in interactions between organisms, i.e., is an "emergent feature of social situations" (West and Zimmerman, 1987, p. 126). In this view, self-identity or self-awareness is not necessary to possess gender or to be gendered and thus can be ascribed to non-human animals. This external or topdown view of gender is probably the closest approximation of what sex assigned at birth actually is, given that babies are not aware of their gender when the social qualities and expectations of sex are placed onto them. Importantly, cultural and social constructions of sex and associated gender identity, expressions, roles, and gendered experiences can interact with a person's genetic code and other biological expressions of sex (more on this below; also see Sanchis-Segura and Becker, 2016; Cortes et al., 2019; Khramtsova et al., 2019). As a result, scholars continue to debate the inherent embeddedness of the biological and socio-cultural aspects of sex and gender, some adopting the term "sex/gender" (or gender/sex) to represent the impossibility of the conceptual independence as well as the biological entanglement (e.g., Kaiser, 2012). Note that "male/female" typically refers to sex and "man/woman" usually refers to gender; however, these terms are also often entangled. For further reading on defining and discussing intersections of sex and gender, see Muehlenhard and
Peterson (2011), Wood and Eagly (2015), Clayton and Tannenbaum (2016), Madsen et al. (2017, see their Table 1 for glossary of terms), and Hyde et al. (2018).

\section{Defining Sex/Gender Differences and Dimorphisms}

Adding the word "difference" to the already complicated meaning of sex, gender, and sex/gender is perhaps even more murky. As will be discussed further in subsequent sections, the dictionary meaning of "difference" is conflated with common statistical language and is confused by science and media communication liberties in reporting as well as societal/historical effects on perceptions of the 'distinctness' that results from category assignment (for review, Eliot, 2011; Joel et al., 2015; Maney, 2016).

A sex difference could be defined as a statistically significant difference in the population means of at least partially overlapping male and female distributions or a meaningful effect size following meta-analysis. The media and general public often instead misinterpret reported sex differences as indicating non-overlapping, distinctly different male and female forms; this characterization instead describes a sexual dimorphism. However, there are also widely varying understandings of sexual dimorphism, which has been defined as "any average sex difference" (Arnold and McCarthy, 2016, p. 2141) but also as indicating "little overlap between the forms of the elements in males and females" (Joel et al., 2015, p. 15468). In a separate collaborative publication, these two camps then converged on this distinction, "for an end point to be truly sexually dimorphic, it needs to exist in two forms, one more prevalent in one sex versus the other" (Joel and McCarthy, 2017, p. 380).

The reviews cited in this section provide excellent discussion on this subject (also see Rippon et al., 2014; Figure 1 in Joel and McCarthy, 2017, "A framework for interpreting sex differences"). For exciting debate on the definition, meaning, and origin of sex differences, see Fine et al. (2019a) followed by a Psychology Today "counterpoints" rebuttal by Del Giudice et al. (2019), and subsequent response by Fine et al. (2019b).

\section{LAYING THE FOUNDATIONS: THE BIOLOGY OF SEX \\ A Brief but Essential Lesson in the Evolutionary Biology of Sex}

To understand the determination of biological sex, it is important to start with some consideration of the evolutionary history of sexual reproduction. Constraints on gamete survival and effectiveness at producing viable offspring led to anisogamy, the existence of two distinct forms of gamete that each contain half of the genetic material of the parent organism: one large and immobile (the ova or female form); the other small and mobile (the sperm or male form). Likewise, the cellular tissue that produces, surrounds, and facilitates the two distinct forms of gamete coevolved to meet the reproductive demands of its respective gamete type, resulting in dimorphic sexual organs including the gonads and other anatomical components. 
Some species are hermaphroditic, possessing both gamete types and accompanying organs within the same individual, separated spatially on the body or temporally switching within the individual's lifespan. (Note: the term "hermaphrodite" is a scientific designation for certain species and is not appropriate or accurate to describe humans with an intersex condition.) Alternatively, the concept of "two sexes" emerges as a result of the gametes and gamete support organs occurring in separate bodies or individuals within a species: one male possessing sperm and one female possessing ova. For such species, the corresponding bodies and nervous systems evolved alongside, and in service to, the gamete, enabling species survival through reproduction. As a result, most sexually reproducing species with two separate sexes, including humans, exhibit 1) competition between the sexes and resulting sexual selection as well as 2) sex differences in anatomy and behavior. These differences may only apply to certain traits, can be subtle or drastic, and are often specific to aspects of anatomy and behavior that pertain to reproduction. Because species survival is also benefited by interindividual genetic variability and phenotypic plasticity, individuals within a population of any species will vary with respect to their expression of sex-biased traits, and these differences can be heightened or suppressed by unique selection pressures within sub-populations of the species (e.g., regional differences in the magnitude of sex differences in body size). Uncovering this nuance, including the consequences of competition between the sexes on more complex traits, is an active area of scientific research and debate. For comprehensive review of these concepts and recommended reading, see Bachtrog et al. (2014), Clutton-Brock (2007; 2017), Kekäläine and Evans (2018), Lehtonen and Parker (2014), Puts (2016), Schmitt et al. (2017), Servedio and Boughman (2017), and Wood and Eagly (2002).

\section{Sex Determination and Differentiation}

For species with two sexes, distinct biological processes determine the organism's sex and then carry out the process of differentiating the relevant anatomy. In many species, the sex of the offspring is programmed at the time of gamete fusion (fertilization) when the chromosomal set, or complement, is established (e.g., $\mathrm{XX}$ or $\mathrm{XY}$ ). Despite this initial programming, the early embryo contains a reproductive system primordium that has the potential to differentiate as male or female. A genetic sex-determining factor contained within the sex chromosomes initiates differentiation and therefore canalizes the anatomical, hormonal, and reproductive fate of the organism. In genotypic determination, as opposed to environmental determination, the initiating signal is a principal gene followed by a cascade of genetic activity that expresses or suppresses genetic code for developing sexually dimorphic gonadal tissue. The specific initiating genetic signals and pathways are variable across species and are highly complex, complete with male and female pathway antagonism and feedback loops. Following gonadogenesis, further signaling initiates hormonal events that differentiate sexual anatomy and organize or program certain micro and macro cellular architecture in other areas of the body, including the brain (more on this below). For review and recommended reading on sex determination and differentiation, see Arnold (2020), Arnold and McCarthy (2016), Capel (2017), Cotinot et al. (2002), McCarthy (2020), and Rey et al. (2020).

The "general theory of sexual differentiation" states that all biological sex differences are downstream of the sex chromosome composition and complement in species with genetic sex determination (Arnold, 2017; also see earlier work by Eicher and Washburn, 1983; 1986). The notion of genetic superiority in determining sex is a more recent advancement over the prior model of gonadal determination whereby all sex differences were thought to be downstream from the differentiation of gonadal tissue and cascading hormonal effects on sexual anatomy and physiology (see the classic work by Alfred Jost). The paradigm shift to acknowledge and emphasize the genetic determinants of sex was aided by an extensive body of research. For the purpose of instruction, we highlight some key "teachable" sources of evidence below:

- The "Four Core Genotypes" mouse model offers an approach to study the independent effects of genetic factors, i.e., the sex chromosome complement, versus gonadal and hormonal factors on sex expression (For review, Arnold and McCarthy, 2016; Figure 2 of that article provides a helpful visual).

- "Gynandromorphism" in birds, butterflies, and other animals is a phenomenon wherein an organism expresses the sex-biased phenotype of both the male and female dimorphism. In bird gynandromorphs this is clearly displayed as bilateral asymmetry in feather pattern and coloration. Studying the underlying mechanism of gynandromorphism has revealed that in some species, the sex chromosome composition inherent to the cells of the body and brain also governs the differentiation processes independent of hormonal exposure (e.g., Agate et al., 2003).

- In humans and other animals, imbalance in the size and composition of the genetic material of the $X$ and $Y$ chromosomes produces a host of other genetic mechanisms that create imbalances between the sexes in some aspects of physiology, while simultaneously reducing imbalances in others. The Xist gene and $X$ inactivation in $X X$ individuals offer an example of this phenomenon and is described in further detail in Section IV. Through a genetic-focused understanding, a paradoxical view of sexual differentiation emerges: mechanisms for sex-chromosome-specific gene expression both increase and decrease sex differences in phenotype (Arnold, 2020).

- Recent advances in genetics and methods for GenomeWide Association Studies (know as "GWAS") will continue to reveal population-level genetic markers for sex-biased effects and intervening gene-byenvironment effects on complex human traits, with specific implication for health and disease (Flint, 2013; Khramtsova et al., 2019). 
Following processes set in motion by sex chromosome complement and resulting patterns of gene expression, gonadal hormone (androgen and estrogen) production and action carry out additional processes of differentiating sexual anatomy and other tissues of the body as well as certain behaviors (for review, Berenbaum \& Beltz, 2011). The predominant theory for understanding hormonal effects on sexual differentiation is the organizational-activational hypothesis (Phoenix et al., 1959; for review, Arnold, 2009; Schulz et al., 2009), which has particular relevance for reproductive behavior.

According to the organizational-activational hypothesis, exposure to gonadal hormones during critical windows in development permanently organizes peripheral and certain central nervous system cellular architecture and gross anatomy. These physiological changes program sex differences in adult patterns of hormone exposure. Thus, there are two main ways in which gonadal hormones produce asymmetries in sexual differentiation of physiology and behavior: 1) organizational; relatively permanent or irreversible, occurring during critical windows and 2) activational; temporary and set in motion by organizational processes. Through activational effects, hormones serve as primary mechanisms for detecting and responding to changes in the organism's internal and external environment. The hormonal theory of sexual differentiation has now been expanded to include downstream effects on genetic, immunological, and epigenetic factors that influence the emergence of sex differences (McCarthy, 2020)

\section{COVERING TOPICS ON GENDER/SEX IN THE BRAIN}

Following the basics of sexual differentiation is the important issue of the extent to which those processes, interacting with broader concepts of sex/gender, impact the tissues of the central nervous system and resulting multitudes of cognitions and behaviors. The field of neuroscience has championed some of the greatest debates as well as scientific advancements on the role of sex/gender in anatomy and behavior. With this work, the value of studying sex differences runs headlong into the consequences of over- or mis- interpretation. For example, the recent $\mathrm{NIH}$ mandate to include equal representation of female and male subjects in animal research has provoked debates in the field (Clayton and Collins, 2014; Shansky and Wooley 2016; Eliot and Richardson 2016). Other ongoing scholarly debates surrounding the nature, degree, and function of sex differences in the brain indicate that much remains to be discovered. Furthermore, public communication and application of existing findings has proven to be problematic (e.g., Pavlova, 2017; Rippon, 2019; Eliot et al., 2021).

So what is a useful way to summarize the current state of our knowledge? Sex differences in the nervous system do exist and are well-documented in a variety of model organisms (including humans); however, in many cases such "differences" reflect highly overlapping male and female population distributions. It is also likely the case that sex differences observed in adult animal brains and behavior reflect some combination of "hard-wired" genetic programming during development and experiencedependent changes to the nervous system. Below, we discuss two common frameworks in which this work will be encountered.

\section{The Benefits of Researching Sexually Dimorphic Neural Circuits as Experimental Models}

Neuroscientists study the ways in which the nervous system differs between the sexes for a number of reasons. For one, sexually dimorphic behaviors and their underlying neural circuits in non-human animal models are useful experimental systems to elucidate general principles about the nervous system. Sexually dimorphic behaviors that are critical for species survival are, with some exceptions like birdsong vocal learning, innate, meaning that they do not need to be learned by the organism (Bertram et al., 2020; McKinsey et al., 2018; Jennings and de Lecea, 2020). Such innate behaviors are mediated by underlying neural circuits that are at least partially genetically encoded; this provides a genetically tractable entry point to interrogate how the nervous system gives rise to behavior.

Sexually dimorphic neural circuits and behaviors by definition exist in either "male-typical" or "female-typical" forms. Therefore, sexually dimorphic behaviors can be used to assess the ability of specific genetic, hormonal, or other manipulations to phenotypically "switch" a neural or behavioral characteristic from one form to another. For many examples of this type of literature, see Dickson and Dulac (2016), Emmons (2018), Zilkha et al. (2017), McKinsey et al. (2018), and Auer and Benton (2016).

Importantly, sexually dimorphic and other innate behaviors are also modifiable by experience and the internal state of the animal (e.g., Dulac et al., 2014; Anderson, 2016; Kim et al., 2017; Wei et al., 2021). Consequently, the study of sexually dimorphic behaviors in a variety of model organisms has also provided generalizable principles about experience- and state-dependent plasticity of the nervous system. This body of literature can therefore be used to achieve a number of goals in the course, such as: 1) highlighting the research that revealed key tenets of our modern understanding of sexual differentiation of the nervous system, 2) introducing students to cutting-edge experimental tools in neuroscience, and 3) illustrating the ways in which both "innate" genetic programs and experience and/or environment sculpt nervous system form and function.

An important discussion point to highlight in this context is that sexually dimorphic behaviors and circuits found in non-human animal models are not directly translatable to humans due to differences in biology. For example, humans do not possess the same pheromone-sensing apparatus that mediates many sexually dimorphic behaviors in mice (Dulac and Torello, 2003) and experience greater influence of social constructs governing behaviors related to reproduction.

\section{The Benefits (and Challenges) of Studying Sex as a} Biological Variable (SABV) in the Nervous System

A second motivation to study sex and gender differences in the nervous system is to gain insight into both healthy 
physiology and disease states. Many neurological disorders exhibit sex/gender biases in their prevalence, with early-life disorders more common in men and neurodegenerative conditions more prevalent in women (McCarthy, 2016). These disparities suggest that there exist physiological differences between the sexes/genders that have important consequences for nervous system function and vulnerability and/or resistance to disease. A great deal of evidence demonstrates that male and female physiology differ in many ways beyond those directly subserving reproductive behaviors (e.g., gene expression in adipose tissue), and that even differences found beyond the brain or gonads have functional implications for the nervous system and behavior (de Vries and Forger, 2015).

Unfortunately, the full extent to which sex/gender differences in physiology exist-both within and beyond the realm of neuroscience-is still largely unknown, due to the historical underrepresentation and exclusion of female subjects from biomedical research. Although the exclusion of females has been most egregious in studies using nonhuman subjects (Beery and Zucker, 2011; Will et al., 2017), the problem has even extended to human clinical trials. From 1977 until 1993, US Food and Drug Administration (FDA) guidelines excluded women from clinical research trials, and women continued to be underrepresented in clinical trials for years after the guidelines were revised (Seydel, 2021). A primary rationale for excluding female animals and women from research studies is the assumption that females introduce greater variability to the experimental paradigm due to hormonal fluctuations of the estrus/menstrual cycle; however, these concerns are unfounded (Prendergast et al., 2014; Shansky, 2019; Seydel, 2021).

Beyond simply limiting our understanding of brain function to the male context, the exclusion of females has had clinical repercussions. A recent meta-analysis identified sex differences in pharmacokinetics for the majority of FDAapproved drugs examined, and these sex differences strongly predicted sex-specific adverse drug reactions in women, but not men (Zucker and Prendergast, 2020). In some cases, drugs have been withdrawn from the market due to their greater health risks posed to women; these risks were not identified prior to the drug coming to market due to the exclusion of female/women subjects in drug testing studies (Seydel, 2021).

To remediate the exclusion of females from research studies, the US National Institutes of Health (NIH) mandated that beginning in 2016 sex must be considered as a biological variable in all studies-including research in nonhuman animal models and studies using primary cell linesunless strong justification for including just a single sex was provided (Clayton and Collins, 2014); similar guidelines for the inclusion of sex and/or gender in research studies have been adopted by funding organizations elsewhere in the world (Lee, 2018). Specifically, NIH guidelines instruct researchers to "develop a data analysis plan prospectively that, at a minimum, provides for the collection of data disaggregated by sex" (NIH, 2015). Consequently, recent years have seen renewed emphasis and discussion of sex differences in neuroscience research, even in dedicated themed journal issues, which offer many useful course materials (e.g., Dickson and Dulac, 2016; McCarthy, 2016; Cahill, 2017).

Although the $\mathrm{NIH}$ mandate has been praised as a positive step towards a fuller understanding of nervous system function (Shansky and Woolley, 2016) concerns about the policy's implementation have been raised (Eliot and Richardson, 2016; Joel and McCarthy, 2017; GarciaSifuentes and Maney, 2021). For one, the mandate emphasizes "sex" devoid of critical context like the interplay of sex and gender (for human studies) and nuance about the nature of sex differences, including the fact that a sex difference reflects an offset in two (often mostly) overlapping male and female populations and that sex is merely an indirect proxy for other biological variables responsible for differences in physiology or behavior (Springer et al., 2012; Maney, 2016).

Second, the mandate requires the investigation, reporting, and interpretation of observed sex differences by researchers untrained in thinking about or designing experiments to study sex differences. This requirement poses a major challenge for the interpretation of such results, including any clinical implications (Eliot and Richardson, 2016; Maney, 2016; Garcia-Sifuentes and Maney, 2021; Rippon et al., 2021). The example of the sleep aid Zolpidem (commonly known as Ambien) highlights some of these challenges: the FDA ultimately issued gender-specific dosing recommendations following reports of slower drug clearance and increased drug-induced driving impairment in women once the drug was on the market (Maney, 2016; Seydel, 2021); however, recent analyses have called the originally reported sex differences into question (Greenblatt et al., 2019), challenging the validity of these gender-specific dosing guidelines.

Non-human research models are limited in their ability to model gender, further complicating inferences from such studies for human health. Fortunately, several resources to train researchers in the study of SABV have been developed, including a short course on the topic offered at the annual Society for Neuroscience conference in 2018. The materials for that course are freely available for download at https://www.sfn.org/careers/career-tools-andresources/scientific-short-courses.

\section{FRAMING THE NOW VS. THEN DEBATE TO DISPEL MISCONCEPTIONS}

The research on sex/gender differences in brain and behavior is highly complex, spanning a wide range of scientific areas of study and levels of analysis, and undergoing continual and rapid growth. Teaching on the biology of sex will inevitably intersect with students' preconceived notions of sex formed through social and cultural learning and psychological aspects of sex/gender identity. To help educators grapple with decision of what to include in their course-a decision made more difficult against a backdrop of time constraints and considerations about balancing complexity versus simplicity-we recommend the key topics described below. We encourage instructors to contrast current understandings of the below topics with prior notions/folk wisdom when teaching this 
material, as is summarized in Table 1. Doing so will provide a helpful framework for dispelling misconceptions and will powerfully illustrate the meaningful distinction between what might otherwise seem to be subtle nuance.

\section{Biological sex is multi-level, interacts with the} environment, and can be non-matching across level.

The traditional understanding of sexual differentiation is that it results in strict categories of biologically male or female, an absolutist and fixed-fate vision of the end-product. Although certain facts are indeed black-and-white, e.g., reproduction requires the two dichotomous forms of gamete, there is some notable flexibility in overall phenotypic expression.

\begin{tabular}{|c|c|c|}
\hline & Current Understanding & Outdated/Traditional View \\
\hline 1 & $\begin{array}{l}\text { Biological sex is multi-level, } \\
\text { interacts with the } \\
\text { environment, and can be } \\
\text { non-matching across levels. }\end{array}$ & $\begin{array}{l}\text { Biological sex is universally } \\
\text { dichotomous and fixed. }\end{array}$ \\
\hline 2 & $\begin{array}{l}\text { There are many important } \\
\text { end-products of sexual } \\
\text { differentiation. }\end{array}$ & $\begin{array}{l}\text { Genitalia are the primary } \\
\text { end-point of differentiation. }\end{array}$ \\
\hline 3 & $\begin{array}{l}\text { Sex differentiation requires } \\
\text { "active" and complex } \\
\text { genetic signaling in both } \\
\text { males and females }\end{array}$ & $\begin{array}{l}\text { Female anatomy and } \\
\text { physiology is "passive" } \\
\text { whereas the male form is } \\
\text { "active." }\end{array}$ \\
\hline 4 & $\begin{array}{l}\text { The timing and pattern of } \\
\text { exposure of so called "sex" } \\
\text { hormones, i.e., androgens } \\
\text { and estrogens, are most } \\
\text { important for understanding } \\
\text { sexual differentiation, not } \\
\text { their absolute levels at any } \\
\text { given point in adulthood }\end{array}$ & $\begin{array}{l}\text { Men have male hormones, } \\
\text { e.g., testosterone, and } \\
\text { women have female } \\
\text { hormones, e.g., estrogen; } \\
\text { absolute hormone levels } \\
\text { indicate something about } \\
\text { sex. }\end{array}$ \\
\hline 5 & $\begin{array}{l}\text { Sex differences in brain } \\
\text { structure/anatomy do not } \\
\text { necessitate sex differences } \\
\text { in brain function. At least } \\
\text { some sex differences in the } \\
\text { nervous system likely arise } \\
\text { as mechanisms to make } \\
\text { nervous system function } \\
\text { more similar between the } \\
\text { sexes. }\end{array}$ & $\begin{array}{l}\text { Sex differences in structure } \\
\text { or anatomy are always } \\
\text { functionally important and } \\
\text { suggest something highly } \\
\text { meaningful about cognition } \\
\text { and behavior. Sex } \\
\text { differences in the nervous } \\
\text { system always give rise to } \\
\text { differences in nervous } \\
\text { system function and } \\
\text { behavior between the } \\
\text { sexes. }\end{array}$ \\
\hline 6 & $\begin{array}{l}\text { The human brain is a } \\
\text { sex/gender mosaic. }\end{array}$ & $\begin{array}{l}\text { The brain exists in two } \\
\text { distinct forms that are either } \\
\text { wholly "male" or wholly } \\
\text { "female." }\end{array}$ \\
\hline 7 & $\begin{array}{l}\text { Both experience (nurture) } \\
\text { and gene-mediated sex } \\
\text { differentiation mechanisms } \\
\text { (nature) affect biological } \\
\text { systems that produce the } \\
\text { emergent property of Sex. }\end{array}$ & $\begin{array}{l}\text { Socialized experiences of } \\
\text { gender are separate from } \\
\text { and cannot influence the } \\
\text { "purely biological" } \\
\text { determinants of sex. }\end{array}$ \\
\hline
\end{tabular}

Table 1. Current understanding of key recommended topics for the course, contrasted against outdated or traditional notions.

See Figure 1 in Khramtsova et al., 2019 for "factors contributing to phenotypic sex differences (p. 177)" that include numerous endogenous (e.g., patterns of hormone exposure) and environmental (e.g., exposure to pesticides) factors as well as known and yet-to-be-discovered nuance in genetic variability, genome expression, and genomeenvironment interactions. Although the mechanisms are not well understood, socialized experiences of gender exert some epigenetic effects that alter what are otherwise thought of as "purely biological sex differences" (see perspectives in Cortes et al., 2019 and Sanchis-Segura and Becker, 2016).

Additionally, atypical genetic expression, sex-signaling genetic co-factors, exposure to environmental hormones, and random mechanistic snafus can and do result in phenotypes beyond or in-between the categorical classification of "female" or "male." Biological sex can be "non-matching" across the various levels of classification e.g., having a chromosome pair that is, in most individuals, matched with sperm-producing gonads is instead matched with ambiguous or otherwise non-sperm producing gonads. A discussion of the wide variety of differences (formerly referred to as "disorders") of sexual differentiation (DSDs) and the intersex phenotype is a helpful demonstration of 1) the resulting anatomy given the presence or absence of critical genetic and hormonal signaling and 2) the difficulty of defining sex in terms of distinct categories. The following resources are particularly helpful for guiding these discussions: Ainsworth (2015), Bramble et al. (2017), Montañez (2017), Walia et al. (2018), and Radiolab: Gonads Series

(https://www.wnycstudios.org/podcasts/radiolab/projects/ra diolab-presents-gonads).

\section{There are many important end-products of sexual differentiation.}

The most ostensibly visible aspects of biological sex, the external genitalia, are often used in human sex-assignment at birth, but can be unreliable indicators of underlying sexlinked biology. What traditionally follows from a lesson in 'sex determination' is the textbook rendering of masculinization-feminization: a two-column, flow-chart figure whereby an undifferentiated uro-genital ridge morphs, by way of arrow and corresponding chromosome pair, into disembodied tubes and gonads and culminating with, as seen at birth, fully distinguishable prepubescent genitalia.

Although much of the genetic and anatomical complexity is passed over, perhaps understandably so, such a figure does not shy away from the notion of macro-anatomical omnipotence for determining an individual's sex or the notion that external genitalia are the mechanistic end-point. The long-term effects of this socially constructed conception persist into medical training, at least historically, where sex assigned at birth and "sex-conforming" surgeries are made on the basis of the insidious idea that genitalia are the primary endpoints of the process of sexual differentiation. Neuroscience has long been plagued by a bias towards the grossly observable, a fact that has also led to inescapable misconceptions about brain function (Barrett, 2020).

Contrary to the genitalia fixation, perhaps the most important anatomical changes that occur or at least are programmed during sexual differentiation-and are arguably most dimorphic between typically developing males and 
females-are 1) gonad cellular structure and function, 2) the timing and mechanism of the development of sex gametes from primordial germ cells, and 3 ) the associated adulthood pattern of hormonal exposure (more on this below). Figures 1-3 in McCarthy (2020) may serve as a replacement or, at least, a complement to the traditional gross anatomy differentiation chart. Additionally, see Figure 1 in Estermann et al. (2020) for a visual rendering of the cellular architecture resulting from gonadal sex differentiation as well as Figures 1 and 2 in Grinspon and Rey (2019).

\section{Sex differentiation requires "active" and complex genetic signaling in both males and females.}

Another common misconception of the sexual differentiation process is the female-by-default model, whereby $X Y$ individuals experience an "active" differentiation, the male form developing above and beyond the "passive/default" female form (see contrast drawn in Figure 2 of SanchisSegura and Becker, 2016). Although more is known about the hormonal mechanisms that differentiate male tissues, female-typical anatomical organization and behavior also requires specific genetic signaling and downstream hormonal patterns of exposure (Eicher and Washburn, 1986; Nef et al., 2005).

An underappreciated example of active female differentiation is the process of $X$-inactivation in $\mathrm{XX}$ individuals. This process involves genetic signaling from the Xist gene to activate the suppression of one of the $X$ chromosomes to compensate for the fact that it contains significantly more genetic material than the $Y$ chromosome (reviewed by Arnold, 2017). This phenomenon results in what is known as X-mosaicism, meaning that the cells of a female body contain a mixture of maternally and paternally sourced $X$ chromosomes. These chromosomes can be maternal-X-dominant or paternal-X-dominant. Importantly, $X$-mosaicism is unique to $X X$ individuals; the entirety of the cells of $X Y$ individuals always and only contain maternallysourced $X$ chromosomes and resulting maternally-linked genes. For further reading and additional educational material see Ahn and Lee (2008).

\section{The timing and pattern of exposure of so-called "sex" hormones, i.e., androgens and estrogens, are most important for understanding sexual differentiation, not their absolute levels at any given point in adulthood.}

The most impactful hormonal difference between the sexes is not absolute levels of a particular "male" or "female" hormone. Instead, what is most critical for effects on anatomy and behavior is the difference in long-term and total exposure to particular hormones during critical developmental windows (see discussion of the organizational-activational hypothesis above). Both male and female adults produce androgens and estrogens and these two hormones are just one enzymatic conversion from each other in a complex steroid hormone pathway. The presence or absence of certain enzymes in tissues send prohormone substrates down a path that leads a functional endpoint: All testosterone and estradiol come from a prior progesterone form; the presence of a particular enzyme (aromatase) in gonads determines whether more or less testosterone is converted to estradiol.

Importantly, although there are notable differences in absolute levels of testosterone, (e.g., average differences between adult males and females), this fact is less important for producing sex differences in anatomy and behavior than the amount and pattern of exposure during developmental critical windows (Berenbaum and Beltz, 2011). For example, research on the psychological and behavioral effects of androgen exposure in development support moderate to large effects of androgens on gender-typed activities and interests such as social play (e.g., Spencer et al., 2021, for review, Berenbaum and Beltz, 2021; Collaer and Hines, 1995). However, the size of the effects and the methods for determining androgen exposure are debated (Collaer and Hines, 2020; Hines et al., 2015).

The effects of sex differences in androgen exposure on physiology are thought to form the basis of population-level sex differences in athletic ability and performance and the subsequent separation of the sexes in formal sport (for review, Handelsman et al, 2018; Hilton and Lundberg, 2020; Wood and Stanton, 2012). However, the notable existence of variability in androgen exposure due to differences of sexual differentiation and other environment or endogenous factors complicates the notion of sex determination for the purposes of inclusion in women's sport. Indeed, recent highprofile banning of "high testosterone" female athletes from certain sanctioned contests has amplified the issue into the public spotlight (see, Farrell, 2019; HHMI Biointeractive "Sex Verification for Athletes," linked below). Furthermore, there has also been recent debate surrounding the question of whether or not transgender women and girls should be able to compete in sanctioned women's sporting contests. In all of these discussions, the biological "truths" about sex, including "facts" about testosterone in particular, are often thrown around carelessly and without full understanding of the underlying complexity (e.g., the effects of hormonal exposure during critical windows). Inevitably, weaponizing faulty biological explanations to justify discrimination or, denying firm biological evidence to condemn it, will offer no clear solutions to moral/ethical dilemmas of this sort. For a helpful discussion and teaching resource on the "ways in which biological influences on gender development are misunderstood, along with examples that counteract and correct the errors" (p. 206), see discussion and Figure 2 in Berenbaum and Beltz (2021). Also see the HHMI Biointeractive "Sex Verification for Athletes" (https://media.hhmi.org/biointeractive/click/testingathletes/introduction.html) for coverage of the use of testosterone levels for sex determination of women athletes.

5. Sex differences in brain structure/anatomy do not necessitate sex differences in brain function. Some sex differences in the nervous system make the nervous system function more similarly between the sexes.

The extent to which sex differences in the nervous system are prevalent and functionally significant is an extensively debated topic in the field. As such, educators exploring this topic for the first time will be confronted by both fierce advocates of sex differences as being of paramount 
importance (e.g., Cahill, 2006) and by more tempered approaches by researchers who point to relatively small effect sizes and the largely non-existent causal relationships between observed sex differences in the brain and functional consequences for behavior (Eliot et al., 2011; Maney, 2015; Maney, 2016; de Vries and Södersten, 2009; Eliot et al., 2021). Despite the many catalogued examples of sex differences, the functional consequences of these differences are far less understood. Due to the fact that the sex hormone manipulations used in animal models to masculinize or feminize the nervous system simultaneously affect all sex hormone-mediated developmental events, such studies are unable to establish which of the many observed sex differences at the cellular, molecular, or morphological level may causally produce a given behavioral sex difference.

Furthermore, the presumed functional consequences of structural differences in the nervous system between the sexes are often assumed to be divergent; that is, leading to differences in behavior. However, sex differences in the nervous system likely also arise as convergent mechanisms, compensating for the different hormonal milieus and genetics of the two sexes to produce similar behaviors (deVries, 2004; deVries and Södersten, 2009; deVries and Forger, 2015). X-inactivation, discussed above, is one example of a compensatory mechanism in sexual differentiation. Caution must therefore be applied when interpreting experiments in the field, especially when attempting to extrapolate from animal models to humans.

When approaching this content, it is useful to recognize that "sex" is, in fact, an indirect proxy for underlying biological factors of interest, such as hormone exposure or gene expression. Science should work to uncover those factors rather than pooling them under the variable of "sex," especially because using "sex difference" as an explanatory mechanism can be more misleading than informative (Jordan-Young and Rumiati, 2012; Maney, 2016).

\section{The human brain is a sex/gender mosaic.}

As described above, biological sex is defined and described along many axes, including chromosomal composition, reproductive organ identity, external genitalia and sex characteristics, and sex hormone levels. Considering these factors together and incongruities between factors, some have argued that sex exists as a continuum and that the binary model is too simplistic to explain biological variation particularly when referring to non-reproductive organs like the brain (Fausto-Sterling, 1993; Ainsworth, 2015). Eliot and colleagues (Eliot et al., 2021) argue that researchers "dump the 'dimorphism"' altogether when discussing human brain studies due to the fact that reported brain differences between the sexes are overwhelmingly trivial and population-specific. Although common inquiries seek to identify and quantify sex differences in the size, morphology, and activity patterns of disparate brain regions, there is evidence that male and female brains exist as mosaicsexhibiting both "male-typical" and "female-typical" formswhen described in these terms (Joel et al., 2015; Joel and Fausto-Sterling, 2016). For an excellent recent review on the topic, see Joel (2021).
7. Both experience (nurture) and gene-mediated sex differentiation mechanisms (nature) affect biological systems that produce the emergent property of sex.

Similar to the fallacy of the nature/nurture "debate", a common approach to understanding sex/gender differences is to parse innate or pre-determined differences from those arising from experience. A large body of work using animal model organisms has elucidated many genetic and developmental determinants of neural circuit structure that give rise to innate behaviors; however, a wealth of evidence has also demonstrated that innate behaviors are subject to modulation by experience and the environment (e.g. Dulac et al., 2014; Anderson, 2016; Kim et al., 2017; Wei et al., 2021). Notably, many of the sex hormone-mediated mechanisms of nervous system sexual differentiation that have been identified involve epigenetics, a common substrate through which experience is translated into biological and physiological changes (McCarthy et al., 2009; McCarthy and Nugent, 2015; McCarthy, et al.,2017; Cortes et al., 2019).

Even in animal models that are not subject to the same societal/cultural influences that humans experience, it is clear that "genetically hard-wired" features of the nervous system can be changed by experience. It is therefore also likely that many of the sex/gender differences that have been studied and highlighted in humans reflect a combination of both pre-patterning (e.g., by genes and sex hormones) and environmental and experience-dependent modulation (e.g., by epigenetic mechanisms). Indeed, gender itself may leave an epigenetic imprint on the brain (Cortes et al., 2019).

Ultimately, effects of the environment and experience are almost certainly going to play a larger role in humans, who are raised and socialized in a gendered society. This reality is at odds with the common interpretation of sex/gender differences as evidence that men and women are fundamentally and innately different (Gray, 1992; discussed in Young and Balaban, 2006; Cahill, 2014).

\section{EXPLORING THE (MIS)REPRESENTATION OF THE NEUROSCIENCE OF GENDER/SEX}

The idea of sex differences in the nervous system (and in particular, the human brain) has long fascinated the general public; public consumption of sex difference research has been likened to a circus (Maney, 2015) due to rampant misrepresentation, misinterpretation, and sensationalizing of research results in the field by the media...and sometimes by the researchers themselves. Especially as conveyed in the popular press, empirical data on neural sex differencesand even on sexual dimorphisms specific to non-human animal models-are used to explain or confirm anecdotally experienced and stereotypically-assigned behavioral differences between men and women (e.g., Eliot, 2011; Nixon, 2011; Lewis, 2013; discussed in Rippon, 2020; Rippon et al., 2021). Interestingly, the degree to which sex differences are described as having a biological basis in the popular press varies based on the political leanings of the publication; readers who are exposed to "biological" explanations for sex differences are more likely to embrace 
traditional gender stereotypes (Brescoll and LaFrance, 2004).

The stakes are high when reporting sex/gender differences in the nervous system, as any neurobiological comparisons between different social groups can lead to stigmatization or stereotyping of those groups (Rippon et al., 2021). Indeed, research in this area is regularly wielded to justify or defend discriminatory social policies and structures. A familiar example is the 2005 speech by thenPresident of Harvard University, Larry Summers, in which he cited research (and anecdotal data) to speculate that women are underrepresented in STEM fields primarily because women prioritize "family desires" over highpowered and intense jobs and because of differences in "intrinsic aptitude" in STEM fields between men and women (Summers, 2005). (He considered "socialization and continuing discrimination" as being only minor factors contributing to the ongoing underrepresentation of women in STEM.) More recently, the infamous "Google Memo" (Damore, 2017) argued that Google's diversity initiatives to increase representation of women at the company were misguided because women are simply less interested in (and suitable for) this type of work, a claim the author attributed to underlying biological differences between men and women and supported with many citations from psychology research. And of course, students today bear witness to ongoing anti-transgender legislative efforts that are championed in the name of "science" (summarized by Schneiberg, 2021).

Given the rampant misuse and distortion of research in this area, the topic of sex/gender differences in the nervous system lends itself to important learning goals related to the critical reading of primary research literature and popular press articles in which research results are discussed, as well as learning goals relevant to science communication. Many recent articles (e.g., Eliot, 2011; Barron and Brown, 2012; Maney, 2015; Maney, 2016; Rippon et al., 2021) highlight the logical fallacies and sensationalizing of results that continue to plague the field of sex differences and provide strategies for researchers to avoid common missteps in research and science communication practices; such articles also serve as excellent teaching tools in the undergraduate classroom.

Key ideas relevant to understanding the meaning and functional significance of sex differences to incorporate into the course include the meaning of a "sex difference" as reported in the scientific literature-i.e., a statistically significant difference in the population means of at least partially overlapping male and female distributions (McCarthy and Konkle, 2005; Maney, 2016)-and the fact that statistical significance is not equivalent to functional significance for the organism. The concept of effect size (e.g., as measured by Cohen's d) is one tool that students can use to assess the size of reported sex differences (derived from a comparison of variation within a population to that between populations). SexDifference.org (https://sexdifference.org/) is a useful interactive data visualization tool to explore the concepts of effect size and population overlap.

If teaching about science communication within their course, instructors can emphasize how misunderstanding and misinterpretation of basic concepts like "sex difference," statistical significance, and effect size fuel some of the distortion and sensationalizing of research findings in general discourse. For example, the media and general public often depict sex differences as referring to nonoverlapping, distinctly different male and female forms; this characterization instead describes a sexual dimorphism, something that is largely non-existent in the human nervous system (Fine et al., 2019a; Eliot et al., 2021).

Another common misrepresentation of research results is the temptation or desire (sometimes shared by the media and researchers alike) to infer behavioral causation inappropriately from structural/anatomical findings. For example, if there are sex differences in the size of brain region $X$ and in behavior $Y$, and brain region $X$ is thought to be related to behavior $Y$, then a common misstep is to assert that the sex difference observed in the size of brain region $X$ must cause the sex difference in behavior $Y$; this is referred to as the false-cause fallacy (Maney, 2016). The temptation to invoke this fallacy is especially problematic when applied to harmful gender stereotypes-as described in the contemporary examples discussed above-and even more so when research conducted in animal models is inappropriately extrapolated to humans in these efforts.

The field offers many examples of high-profile research studies-and accompanying coverage in the popular pressthat serve as useful case studies to illustrate the problematic repercussions of some of the missteps and poor scientific communication practices described above. One example of an excellent case study for the classroom is a 2014 human imaging study by Ingalhalikar et al. that reported sex differences in connectivity within and between the two hemispheres of the brain, as measured by diffusor tensor imaging (Ingalhalikar et al., 2014a). Problematically, the researchers inferred functional consequences from these structural data, evoking gender stereotypes in the process (Penn Medicine, 2013), and visually represented their data in a way that suggested widespread sex differences in connectivity. Equally problematic is the fact that the researchers did not report the percentage of the large number of connections analyzed for the study that exhibited a sex difference, a common practice that motivated Rippon et al. (2021) to implore researchers to engage in "impression management" when reporting sex/gender differences in the brain.

The 2014 Ingalhalikar study generated a large amount of scientific and popular press discourse. A number of popular press articles and blog posts further distorted and sensationalized the research study; the reporting of the results and the media response themselves became the subject of a subsequent publication (O'Connor and Joffe, 2014). Notably, the 2014 Ingalhalikar et al. study was accompanied by an enthusiastic Commentary (Cahill, 2014), a critical Letter (Joel and Tarrasch, 2014), and a rebuttal Letter from the authors (Ingalhalikar et al., 2014b). These additional documents provide students valuable insight into the scientific publishing process and the mechanisms through which scientific discourse occurs. 


\section{CONTEXTUALIZING SEX/GENDER NEUROSCIENCE RESEARCH WITHIN SOCIETY AND HISTORY}

\section{Essentialism and Complementarity}

Research in the neurobiology of sex, gender identity, and sexual orientation is a particularly salient example of how historical and social frameworks can shape scientific inquiry. Supremacist ideas about various groups' superiority/inferiority sought to confirm false gender and racial stereotypes rooted in ideas of essentialism (the tendency to think that qualities related to gender are innate or fixed) and complementarity (the idea that each gender has strengths and weaknesses that naturally complement one another). Literature concerning the "male-systematizer" and "female-empathizer" duality (Baron-Cohen et al., 2005) taps into essentialism as well as complementarity: it proposes that interest and skill in dealing with "things" versus "people" is hardwired in men and women, respectively. The framework has been used to explain gender differences in occupation, such as scientific careers for men and caregiving careers for women, while tending to disregard socialized factors that could explain gender differences in this realm (Rippon, 2019). Scientific inquiry that rests on stereotypes related to essentialism and complementarity, without properly acknowledging or controlling for socially constructed aspects of gender has led to "neurosexism" within this research area (Rippon, 2020). The conflation of sex and gender within the context of nonhuman research on innate sex-specific behaviors as well as supremacist social contexts have led to problematic assumptions about when and why gender differences arise.

\section{Human Research Ethics}

The history of sex/gender research also includes difficult histories related to the ethics of human subjects research. Within the $20^{\text {th }}$ century, debates in the research community about whether gender identity is innate or learned involved distressing case studies in human subjects, such as the case of David Reimer (Colapinto, 2006). The history of this case and its historical context is incredibly complex, but outlined briefly here. Reimer, a twin, experienced a botched circumcision that ablated his penis. Psychologist Dr. John Money studied Reimer and his twin to support ideas that gender identity is learned from one's environment. Reimer underwent gender reassignment surgery at 22 months of age, was treated with estrogens, and raised as a girl. The twins were also subjected to unethical and invasive therapy sessions by Money meant to teach gender roles. Money initially heralded Reimer's cases as successful evidence supporting the hypothesis that gender identity is shaped by social factors. However, starting in his teenage years Reimer became outspoken as identifying as male and speaking out against his experiences; he suffered debilitating mental health impacts and died by suicide at age 38.

Years after Reimer's case, people whose genitals or gonads don't conform to a binary may still experience "corrective" surgeries without their consent, despite the increased attention to bioethics post-World War II (Reis, 2019). Discussions of research ethics are highly relevant not only to the aforementioned cases, but also for topics such as neurobiological roots of sexual orientation and gender identity (Wolpe, 2004).

\section{Bias within the Enterprise of Science}

Institutionalized racism, sexism, and homophobia have resulted in diverse populations being excluded from the enterprise of science itself (Clark and Hurd, 2020; Shipman, 2015; Hopkins, 2015). Dr. Ben Barres (1954-2017), a pioneer of glial cell research and a transmasculine neuroscientist, wrote about his experiences with sexism in science and how that shaped his advocacy for gender inclusiveness in the sciences (Barres, 2018). He described a scientific community that was first misogynistic and hostile (when presenting as a woman) and then welcoming (when presenting as a man, post-transition). Reflecting on gender bias in science, Barres recalled hearing about a talk attendee remarking that "Ben's work is so much better than his sister's", unaware that the work was in fact done by the same person (Barres, 2006, p.134). At the population level, studies by Leslie et al. (2015) found an inverse relationship between field-specific beliefs about essentialized brilliance, and the proportion of PhDs awarded to women, in both science and non-science fields; this research suggests that field-specific stereotypes may shape who decides to pursue the field. The film Picture a Scientist (Cheney and Shattuck, 2020 ) is a good resource for illustrating lived experiences of women in science and barriers they may face, including structural biases in resource allocation, sexual harassment and assault in research settings, and intersections of racism and gender bias in academic settings.

\section{Representation of Queer Populations in Research over Time}

Reading the literature on sexual orientation and gender identity reveals large shifts in representation and terminology over the past few decades. For example, older papers (and some current papers) use categories of homosexual and heterosexual whereas more recent papers may instead include participant's own categorization of their sexual orientations, or focus more on behavior rather than identity. Similarly, whereas older papers may use the term hermaphrodite (a term still used for animals but not for people), more recent papers may use terms like intersex, disorders of sexual development or diversities of sexual development (Ainsworth, 2015).

Recent societal progress in the de-pathologization and acceptance of LGBTQIA+ identities has revolutionized scientific inquiry surrounding sexual orientation and gender identity, including how participants are categorized/selfcategorized. Juxtaposing course readings on the biological basis of sexual orientation from $\sim 30$ years ago (e.g., LeVay,1991) with more recent literature (e.g., Ganna et al., 2019) allows students to identify large differences in experimental questions, methodology, subject recruitment, and operationalization of sexual orientation and behaviors within the literature. Ganna et al.'s GWAS study (2019) described partnering with gender studies and LGBTQIA+ advocates in presenting their results and participating in science outreach to ensure that their results were presented 
with sensitivity to queer communities and clear about what their results do (and do not) imply.

Although modern neuroscience has become more inclusive on many fronts, vestiges of historical thinking about gender stereotypes still remain in the literature. For example, some modern studies still invoke framings of complementarity and essentialism (Ingalhalikar et al., 2014). To unpack these issues in class, it is useful to assign articles that provide a framework for thinking about the intersections between societal and scientific ideas of gender. For example, Fine et al. (2013) argue that societal gender stereotypes have prevented the neuroscience community from recognizing that experience-dependent plasticity (rather than innate developmental pathways alone) can help shape some of the sex/gender brain differences documented in the literature. Similarly, Maney's (2016) description of fallacies in talking about sex/gender differences helps readers recognize how societal thinking about sex/gender as a binary shapes the processes of hypothesis generation, data collection and analysis, and data visualization.

\section{IMPLEMENTATION NOTES}

Having reviewed major content areas and framing of this content in our courses, we will conclude with some notes about course design and implementation. While these recommendations apply to most classroom settings, the importance of culturing a high-rapport and inclusive classroom is especially important for courses that engage students in topics that may be sensitive or personal.

\section{Constructing a Course around Learning Goals}

In each of our courses, we used a backward design framework (Wiggins and McTigue, 2005) to identify three to five core goals of our course and then select readings, instructional methods, and assignments that help our student population achieve those goals. In many cases, the goals we developed for our courses map to larger educational goals about neuroscience content as well as scientific habits of mind such as critical thinking, experimental design, scientific communication, and information literacy (compiled in Table 2). Consequently, our students complete projects such as research proposals and scientific communication portfolios to show their mastery of both content knowledge and intellectual skills within neuroscience.

\section{Culturing a High-Rapport Classroom}

We end on a note about the importance of a high-rapport classroom culture as an environment for teaching about neuroscience and sex/gender, and provide some tips for building rapport. Classroom rapport-a culture of high trust and engagement both between instructor and students as well as among students-is necessary for the free-flowing discussion and academic risk-taking in which we want our students to engage (Frisby and Martin, 2010). Rapport is particularly essential for learning about the intersections between neuroscience and sex/gender because topics of sex, gender identity, and sexual orientation are deeply personal for many students and instructors. From their own lived experiences, members of the course may bring vastly different views on these topics and varying levels of comfort discussing those views, with the potential to elicit productive as well as problematic conversations.

How can instructors build classroom rapport necessary for complex discussions about science and sex/gender? Such a culture includes respecting people's humanity by calling students and professors by the names and pronouns that they use, which may be different from their legal names or pronouns (Wentling, 2015). "First-day info sheets", especially when crafted with inclusion and equity in mind, are a useful tool for building an inclusive classroom culture (Killpak and Melón, 2020). Collaborative exercises in which students construct and agree on interaction norms early in the term, such as through co-authoring a class contract (Nordstrom et al., 2009; Newbould, 2018), engages students as active stakeholders in building a classroom culture. As part of this exercise, discussing the verbal and nonverbal cues that help enrich class discussion is often helpful for students who may be less familiar with discussion-based classes (Birkenstein and Graff, 2010).

A high-rapport classroom allows for students to grow in their understanding in a supportive environment, to make mistakes, to learn how to correct mistakes and apologize gracefully, and to express discomfort constructively. Instructors should be transparent about the difficulty of some of these conversations. It can help to guide students in setting and adhering to norms for constructive dialogue, including how to express discomfort and how to apologize (one such helpful video on apologizing after being "called out" can be found at: https://youtu.be/C8xJXKYL8pU). Overall, it is important not to entertain conversations that are degrading or marginalizing to diverse identities.

Deliberate and careful choices about course language and images also aids in building an inclusive classroom. Hales (2020) provides useful examples of how language choice surrounding genetics supports a classroom environment that is inclusive of gender, race, and ability. Instructors should be aware that published images may be dehumanizing; for example, inclusion of nude photographs of intersex individuals in the scientific literature pathologizes natural variation and dehumanizes the subjects as photos may have been taken or disseminated without the subjects' consent. Therefore, we recommend not including such photographs in lectures. Finally, prepare students to confront issues of sexism, racism, homophobia, etc. through content notes and discussions about how to confront such topics in the context of the course.

Each of us has lived experience related to sex/gender and sexuality. Social acceptance and affirmation of one's lived experience can be situational to the cultures of a particular campus, region, and nation and particular to moments in history. Those of us whose identities are regularly accepted and affirmed should be aware of the privilege that this confers, and that others may not share our experience. Consulting with your campus' Gender/Sexuality Resource Center or Gender Studies departments when developing a course on sex/gender can be a helpful way to understand the particular gender-related cultures and challenges relevant to students at your institution. 


\section{CONCLUSION}

We hope that this article is a useful resource for those wanting to develop or update courses related to sex/gender and the brain. The resources in this article were drawn from three different courses with slightly different goals, and thus is more comprehensive than any one syllabus. Using a Backward Design framework can help instructors choose which goals to set regarding the skills and content taught in their course. Regardless of the exact skills of content taught, designing and delivering the course in an inclusive way helps students constructively engage with neuroscience issues of societal importance.

Supplemental Information: For additional resources for course planning, design, and implementation, please visit our Open Science Framework page at https://osf.io/ec7sz.

\begin{tabular}{|c|c|}
\hline Neuroscience Learning Goal & Sex/Gender Topics Relevant to Goal \\
\hline $\begin{array}{l}\text { Content knowledge: } \\
\text { - Describe how the nervous system develops over the lifespan } \\
\text { and changes with experience } \\
\text { Describe and apply the tenets of evolutionary biology to } \\
\text { elucidate form and function of the brain }\end{array}$ & $\begin{array}{l}\text { - The evolutionary origins of sex and sex differences } \\
\text { - Sexual differentiation of the nervous system } \\
\text { - } \quad \text { Experience-dependent plasticity in the context of gender } \\
\text { socialization }\end{array}$ \\
\hline $\begin{array}{l}\text { Content knowledge: } \\
\text { - Describe the influence of genes and gene-by-environment } \\
\text { interactions on the nervous system } \\
\text { - Characterize how hormone signaling brings about changes to } \\
\text { biological systems }\end{array}$ & $\begin{array}{ll}\text { - } & \text { Genetic-basis and mechanisms of sexual differentiation } \\
\text { - } & \text { Hypothalamic-pituitary-gonadal axis } \\
\text { - } & \text { Synthesis of steroid hormones } \\
\text { - } & \text { Steroid hormone mechanisms and downstream effects } \\
\text { - } & \text { Organizational and activational actions of hormones }\end{array}$ \\
\hline $\begin{array}{l}\text { Content Knowledge: } \\
\text { - } \quad \text { Contrast modern and historical perspectives in neuroscience } \\
\text { - } \quad \text { Identify paradigm shifts in history of neuroscience } \\
\text { - } \quad \text { Explain how societal and historical factors influenced the } \\
\text { process of scientific inquiry and publication }\end{array}$ & $\begin{array}{l}\text { - } \quad \text { Historical vs. present methodologies for studying the brain } \\
\text { - } \quad \text { Contrasting "Then vs. Now" teachable nuances } \\
\text { - History of racism, sexism, homophobia and impacts on } \\
\text { neuroscience inquiry }\end{array}$ \\
\hline $\begin{array}{l}\text { Experimental Logic: } \\
\text { - Explain how animal models help us understand human } \\
\text { phenomena, including strengths and limitations } \\
\text { - Design and critique experiments, including hypothesis testing, } \\
\text { operationalizing variables, and controlling for confounding } \\
\text { variables. } \\
\text { - Interpret statistical analyses of data: p-value/effect } \\
\text { size/"statistically" vs. functionally" significant, etc. }\end{array}$ & $\begin{array}{l}\text { - Use of non-human animal models for sex differences in } \\
\text { nervous system function } \\
\text { - Sexually dimorphic circuits } \\
\text { - Sex as a Biological Variable in clinical and preclinical } \\
\text { research } \\
\text { - Contrast "sex difference" with "sexual dimorphism", } \\
\text { including statistics and visualizations of these }\end{array}$ \\
\hline $\begin{array}{l}\text { Critical Thinking: } \\
\text { - } \quad \text { Critically read and analyze scientific literature } \\
\text { - } \quad \text { Critical analysis of hypotheses (e.g. validity of assumptions } \\
\text { - } \quad \text { Evat underlie hypotheses) } \\
\text { - } \quad \text { Evaluate the validity of scientific claims by assessing merits } \\
\text { - } \quad \text { Place research findings into a broader context }\end{array}$ & $\begin{array}{l}\text { - Case studies within the areas of sexual differentiation of } \\
\text { the nervous system, sex/gender differences in brain and } \\
\text { behavior, SABV in biomedical research, sexual orientation } \\
\text { and gender identity and the brain } \\
\text { - Nuance underlying the terminology for sex, gender, } \\
\text { sex/gender, sex difference, and sex dimorphism } \\
\text { - Genetic and anatomical compensatory mechanisms for } \\
\text { reducing sex differences in form or function }\end{array}$ \\
\hline $\begin{array}{l}\text { Science Communication: } \\
\text { - Accurately convey scientific results to a non-specialist } \\
\text { audience without sensationalizing them } \\
\text { - } \quad \text { Analyze how results are communicated by others } \\
\text { - Comparison of how results are described in research articles } \\
\text { vs. popular press }\end{array}$ & $\begin{array}{l}\text { - } \quad \text { Readings picked up by the news media, particularly news } \\
\text { articles that translate preclinical animal research to } \\
\text { human relevance. } \\
\text { - Misrepresentation, misinterpretation, and sensationalizing } \\
\text { in interpreting sex "differences" in research }\end{array}$ \\
\hline $\begin{array}{l}\text { Information Literacy: } \\
\text { - Implement citation-chasing strategies while reading } \\
\text { - } \quad \text { Perform targeted literature searches }\end{array}$ & $\begin{array}{l}\text { - Tracking down citations used when articles make broad- } \\
\text { sweeping claims about sex/gender } \\
\text { - Looking up original sources from news articles about } \\
\text { sex/gender and the brain }\end{array}$ \\
\hline
\end{tabular}

Table 2. Broad neuroscience learning goals with paired sex/gender topics that the authors have used towards these goals. 


\section{REFERENCES}

Agate RJ, Grisham W, Wade J, Mann S, Wingfield J, Schanen C, Palotie A, Arnold AP (2003) Neural, not gonadal, origin of brain sex differences in a gynandromorphic finch. Proc Natl Acad Sci USA 100:4873-4878.

Ahn J, Lee JT (2008) X chromosome: X inactivation. Nature Education 1:24.

Ainsworth C (2015) Sex redefined. Nature 518:288-291.

Anderson DJ (2016) Circuit modules linking internal states and social behaviour in flies and mice. Nat Rev Neurosci 17:692704.

Arnold AP (2009) The organizational-activational hypothesis as the foundation for a unified theory of sexual differentiation of all mammalian tissues. Horm Behav 55:570-578.

Arnold AP (2017) A general theory of sexual differentiation: A general theory of sexual differentiation. J Neurosci Res 95:291-300.

Arnold AP (2020) Sexual differentiation of brain and other tissues: Five questions for the next 50 years. Horm Behav 120:104691.

Arnold AP, McCarthy MM (2016) Sexual differentiation of the brain and behavior: A primer. In: Neuroscience in the 21st Century (Pfaff DW, Volkow ND, eds), pp 2139-2168. New York, NY: Springer New York.

Auer TO, Benton R (2016) Sexual circuitry in Drosophila. Curr Opin Neurobiol 38:18-26.

Bachtrog D, Mank JE, Peichel CL, Kirkpatrick M, Otto SP, Ashman T-L, Hahn MW, Kitano J, Mayrose I, Ming R, Perrin N, Ross L, Valenzuela N, Vamosi JC, The Tree of Sex Consortium (2014) Sex determination: Why so many ways of doing it? PLoS Biol 12:e1001899.

Baron-Cohen S, Knickmeyer RC, Belmonte MK (2005) Sex differences in the brain: Implications for explaining autism. Science 310:819-823.

Barres BA (2006) Does gender matter? Nature 442:133-136.

Barres BA (2018) The autobiography of a transgender scientist. MIT Press.

Barrett LF (2020) Seven and a half lessons about the brain. Boston: Houghton Mifflin Harcourt.

Barron AB, Brown MJF (2012) Let's talk about sex. Nature 488:151-152.

Beery AK, Zucker I (2011) Sex bias in neuroscience and biomedical research. Neurosci Biobehav Rev 35:565-572.

Berenbaum SA, Beltz AM (2011) Sexual differentiation of human behavior: effects of prenatal and pubertal organizational hormones. Front Neuroendocrinol 32(2), 183200.

Berenbaum SA, Beltz, AM (2021) Evidence and implications from a natural experiment of prenatal androgen effects on gendered behavior. Curr Dir Psychol Sci 30(3), 202-210.

Bertram R, Hyson RL, Brunick AJ, Flores D, Johnson F (2020) Network dynamics underlie learning and performance of birdsong. Curr Opin Neurobiol 64:119-126.

Birkenstein C, Graff G (2010) They say / I say: The moves that matter in academic writing, Second ed. New York, NY: W.W> Norton \& Company.

Bramble MS, Lipson A, Vashist N, Vilain E (2017) Effects of chromosomal sex and hormonal influences on shaping sex differences in brain and behavior: Lessons from cases of disorders of sex development. J Neurosci Res 95(1-2):65-74.

Brescoll V, LaFrance M (2004) The Correlates and consequences of newspaper reports of research on sex differences. Psychol Sci 15:515-520.
Cahill L (2006) Why sex matters for neuroscience. Nat Rev Neurosci 7:477-484.

Cahill L (2014) Fundamental sex difference in human brain architecture. Proc Natl Acad Sci USA 111:577-578.

Cahill L (2017) An issue whose time has come. J Neurosci Res 95:12-13.

Capel B (2017) Vertebrate sex determination: evolutionary plasticity of a fundamental switch. Nat Rev Genet 18:675689.

Cheney I, Shattuck S (Directors) (2020) Picture a scientist [Film]. Uprising Productions.

Clark US, Hurd YL (2020) Addressing racism and disparities in the biomedical sciences. Nat Hum Behav 4:774-777.

Clayton JA, Collins FS (2014) Policy: NIH to balance sex in cell and animal studies. Nature 509:282-283.

Clayton JA, Tannenbaum C (2016) Reporting sex, gender, or both in clinical research? JAMA 316:1863.

Clutton-Brock T (2007) Sexual selection in males and females. Science 318:1882-1885.

Clutton-Brock T (2017) Reproductive competition and sexual selection. Phil Trans R Soc B 372:20160310.

Colapinto J (2006) As nature made him: the boy who was raised as a girl. New York: HarperCollins.

Collaer ML, Hines M (1995). Human behavioral sex differences: a role for gonadal hormones during early development? Psych Bull 118(1), 55-107.

Collaer ML, Hines M (2020) No evidence for enhancement of spatial ability with elevated prenatal androgen exposure in congenital adrenal hyperplasia: A meta-analysis. Arch Sex Behav 49(2), 395-411.

Cortes LR, Cisternas CD, Forger NG (2019) Does gender leave an epigenetic imprint on the brain? Front Neurosci 13.

Cotinot C, Pailhoux E, Jaubert F, Fellous M (2002) Molecular genetics of sex determination. Semin Reprod Med 20:157168.

Damore J (2017) Google's ideological echo chamber. Available at:

https://assets.documentcloud.org/documents/3914586/Googl es-Ideological-Echo-Chamber.pdf.

de Vries GJ (2004) Minireview: Sex differences in adult and developing brains: Compensation, compensation, compensation. Endocrinology 145:1063-1068.

de Vries GJ, Forger NG (2015) Sex differences in the brain: a whole body perspective. Biol Sex Differ 6:15.

de Vries GJ, Södersten P (2009) Sex differences in the brain: The relation between structure and function. Horm Behav 55:589-596.

Del Giudice M, Puts DA, Geary DC, Schmitt DP (2019) Sex differences in brain and behavior: Eight counterpoints. Psychol Today. Available at: https://www.psychologytoday.com/gb/blog/sexualpersonalities/201904/sex-differences-in-brain-and-behavioreight-counterpoints.

Dickson BJ, Dulac C eds. (2016) Neurobiology of sex [Special Issue]. Curr Opin Neurobiol 38.

Dulac C, O'Connell LA, Wu Z (2014) Neural control of maternal and paternal behaviors. Science 345:765-770.

Dulac C, Torello AT (2003) Molecular detection of pheromone signals in mammals: From genes to behaviour. Nat Rev Neurosci 4:551-562.

Eicher EM, Washburn, LL (1983) Inherited sex reversal in mice: Identification of a new primary sex-determining gene. J Exp Zoology 228(2), 297-304. 
Eicher EM, Washburn LL (1986) Genetic control of primary sex determination in mice. Annu Rev Genet 20(1), 327-360.

Eliot $L$ (2011) The trouble with sex differences. Neuron 72:895898.

Eliot L, Richardson SS (2016) Sex in context: Limitations of animal studies for addressing human sex/gender neurobehavioral health disparities. J Neurosci 36:1182311830.

Eliot L, Ahmed A, Khan H, Patel J (2021) Dump the "dimorphism": Comprehensive synthesis of human brain studies reveals few male-female differences beyond size. Neurosci Biobehav Rev 125:667-697.

Emmons SW (2018) Neural circuits of sexual behavior in Caenorhabditis elegans. Annu Rev Neurosci 41:349-369.

Estermann MA, Major AT, Smith CA (2020) Gonadal sex differentiation: Supporting versus steroidogenic cell lineage specification in mammals and birds. Front Cell Dev Biol 8:616387.

Farrell S (2019, November 15) How do IAAF regulations affect female athletes with high testosterone levels? Global Sport Matters.

Available

at: https://globalsportmatters.com/health/2019/11/15/iaafregulations-for-female-athletes-with-high-testosterone/

Fausto-Sterling A (1993) The five sexes. The Sciences 33:2024.

Fine C, Jordan-Young R, Kaiser A, Rippon G (2013) Plasticity, plasticity, plasticity...and the rigid problem of sex. Trends Cogn Sci 17:550-551.

Fine C, Joel D, Rippon G (2019a) Eight things you need to know about sex, gender, brains, and behavior: A guide for academics, journalists, parents, gender diversity advocates, social justice warriors, tweeters, facebookers, and everyone else. The Scholar \& Feminist Online. Available at: https://sfonline.barnard.edu/neurogenderings/eight-thingsyou-need-to-know-about-sex-gender-brains-and-behavior-aguide-for-academics-journalists-parents-gender-diversityadvocates-social-justice-warriors-tweeters-facebookers-andeverl.

Fine C, Joel D, Rippon G (2019b) Responding to ideas on sex differences in brain and behavior. Psycho Today. Available at: https://www.psychologytoday.com/gb/blog/sexualpersonalities/201907/responding-ideas-sex-differences-inbrain-and-behavior.

Flint J (2013). GWAS. Current Biology, 23(7), R265-R266.

Frisby BN, Martin MM (2010) Instructor-student and studentstudent rapport in the classroom. Commun Educ 59:146-164.

Ganna A et al. (2019) Large-scale GWAS reveals insights into the genetic architecture of same-sex sexual behavior. Science 365:eaat7693.

Garcia-Sifuentes Y, Maney DL (2021) Reporting and misreporting of sex differences in the biological sciences. BioRxiv 2021.05.28.446238 [Preprint]. Available at https://doi.org/10.1101/2021.05.28.446238.

Gray J (1992) Men are from Mars, women are from Venus: The classic guide to understanding the opposite sex. New York, NY: Harper.

Greenblatt DJ, Harmatz JS, Roth T (2019) Zolpidem and gender: Are women really at risk? J Clin Psychopharmacol 39:189-199.

Grinspon RP, Rey RA (2019) Molecular characterization of XX maleness. Int J Mol Sci 20:6089.

Hales, KG (2020) Signaling inclusivity in undergraduate biology courses through deliberate framing of genetics topics relevant to gender identity, disability, and race CBE Life Sci Educ 19(2): es2.
Handelsman DJ, Hirschberg AL, Bermon S (2018) Circulating testosterone as the hormonal basis of sex differences in athletic performance. Endocr Rev 39(5), 803-829.

Harrington M (2020) The design of experiments in neuroscience, Third edition. New York, NY: Cambridge University Press.

Hilton EN, Lundberg TR (2020) Transgender women in the female category of sport: Perspectives on testosterone suppression and performance advantage. Sports Med 1-16.

Hines M, Constantinescu M, Spencer D (2015) Early androgen exposure and human gender development. Biol Sex Differ 6(1), 1-10.

Holmes MM, Monks DA (2019) Bridging sex and gender in neuroscience by shedding a priori assumptions of causality. Front. Neurosci. 13:475.

Hopkins N (2015) Reflecting on fifty years of progress for women in science. DNA Cell Biol 34:159-161.

Hyde JS, Bigler RS, Joel D, Tate CC, van Anders SM (2018) The future of sex and gender in psychology: Five challenges to the gender binary. Am Psychol 74:171-193.

Ingalhalikar M, Smith A, Parker D, Satterthwaite TD, Elliott MA Ruparel K, Hakonarson H, Gur RE, Gur RC, Verma R (2014a) Sex differences in the structural connectome of the human brain. Proc Natl Acad Sci USA 111:823-828.

Ingalhalikar M, Smith A, Parker D, Satterthwaite TD, Elliott MA, Ruparel K, Hakonarson H, Gur RE, Gur RC, Verma R (2014b) Reply to Joel and Tarrasch: On misreading and shooting the messenger. Proc Natl Acad Sci USA 111:E638-E638.

Jennings KJ and de Lecea $L$ (2020) Neural and hormonal control of sexual behavior. Endocrinology 161(10): 1-13.

Joel D (2021) Beyond the binary: Rethinking sex and the brain. Neurosci Biobehav Rev 122:165-175.

Joel D, Fausto-Sterling A (2016) Beyond sex differences: new approaches for thinking about variation in brain structure and function. Phil Trans R Soc B 371:20150451.

Joel D, McCarthy MM (2017) Incorporating sex as a biological variable in neuropsychiatric research: where are we now and where should we be? Neuropsychopharmacol 42:379-385.

Joel D, Tarrasch R (2014) On the mis-presentation and misinterpretation of gender-related data: The case of Ingalhalikar's human connectome study. Proc Natl Acad Sci USA 111:E637-E637.

Joel D, Berman Z, Tavor I, Wexler N, Gaber O, Stein Y, Shefi N, Pool J, Urchs S, Margulies DS, Liem F, Hänggi J, Jäncke L, Assaf $Y$ (2015) Sex beyond the genitalia: The human brain mosaic. Proc Natl Acad Sci USA 112:15468-15473.

Jordan-Young R, Rumiati RI (2012) Hardwired for sexism? Approaches to sex/gender in neuroscience. Neuroethics 5:305-315.

Kaiser A (2012) Re-Conceptualizing "sex" and "gender" in the human brain. Zeitschrift für Psychologie 220:130-136.

Kekäläinen J, Evans JP (2018) Gamete-mediated mate choice: towards a more inclusive view of sexual selection. Proc R Soc B 285:20180836.

Khramtsova EA, Davis LK, Stranger BE (2019) The role of sex in the genomics of human complex traits. Nat Rev Genet 20:173-190

Killpack T, Melón L. 2020. First-day info sheets: a tool to prompt semester-long inclusive teaching. J Microbiol Biol Educ 21(1): doi:10.1128/jmbe.v21i1.1983

Kim SM, Su C-Y, Wang JW (2017) Neuromodulation of innate behaviors in Drosophila. Annu Rev Neurosci 40:327-348.

Laird TFN, Engberg ME (2011) Establishing differences between diversity requirements and other courses with varying degrees of diversity inclusivity. J Gen Educ 60:117137. 
Lee SK (2018) Sex as an important biological variable in biomedical research. BMB Rep 51:167-173.

Lehtonen J, Parker GA (2014) Gamete competition, gamete limitation, and the evolution of the two sexes. Mol Hum Reprod 20:1161-1168.

Leslie S-J, Cimpian A, Meyer M, Freeland E (2015) Expectations of brilliance underlie gender distributions across academic disciplines. Science 347:262-265.

LeVay S (1991) A difference in hypothalamic structure between heterosexual and homosexual men. Science 253:1034-1037.

Lewis T (2013) How men's brains are wired differently than women's. Sci Am. Available at https://www.scientificamerican.com/article/how-mens-brainsare-wired-differently-than-women/.

Madsen TE, Bourjeily G, Hasnain M, Jenkins M, Morrison MF, Sandberg K, Tong IL, Trott J, Werbinski JL, McGregor AJ (2017) Article commentary: Sex- and gender-based medicine: The need for precise terminology. Gend Genome 1:122-128.

Maney DL (2015) Just like a circus: the public consumption of sex differences. Curr Top Behav Neurosci 19:279-296.

Maney DL (2016) Perils and pitfalls of reporting sex differences. Phil Trans R Soc B 371:20150119.

McCarthy MM (2016) Multifaceted origins of sex differences in the brain. Phil Trans R Soc B 371:20150106.

McCarthy MM (2020) A new view of sexual differentiation of mammalian brain. J Comp Physiol A 206:369-378.

McCarthy MM, Konkle ATM (2005) When is a sex difference not a sex difference? Front Neuroendocrin 26:85-102.

McCarthy MM, Nugent BM (2015) At the frontier of epigenetics of brain sex differences. Front Behav Neurosci 9.

McCarthy MM, Auger AP, Bale TL, de Vries GJ, Dunn GA, Forger NG, Murray EK, Nugent BM, Schwarz JM, Wilson ME (2009) The epigenetics of sex differences in the brain. J Neurosci 29:12815-12823.

McCarthy MM, Nugent BM, Lenz KM (2017) Neuroimmunology and neuroepigenetics in the establishment of sex differences in the brain. Nat Rev Neurosci 18:471-484.

McKinsey GL, Ahmed OM, Shah NM (2018) Neural control of sexually dimorphic social behaviors. Curr Opin Physiol 6:89_ 95.

Mead KS (2009) Sex, gender, and the brain: A non-majors course linking neuroscience and women's studies. J Undergrad Neurosci Educ 8:A5-9.

Montañez A (2017) Beyond XX and XY: The extraordinary complexity of sex determination. Sci Am. Available at: https://www.scientificamerican.com/article/beyond-xx-andxy-the-extraordinary-complexity-of-sex-determination/.

Muehlenhard CL, Peterson ZD (2011) Distinguishing between sex and gender: History, current conceptualizations, and implications. Sex Roles 64:791-803.

National Institutes of Health (2015) NOT-OD-15-102: Consideration of Sex as a Biological Variable in NIH-funded Research. Available at: https://grants.nih.gov/grants/guide/notice-files/NOT-OD-15102.html.

Nef S, Schaad O, Stallings NR, Cederroth CR, Pitetti J-L, Schaer G, Malki S, Dubois-Dauphin M, Boizet-Bonhoure B, Descombes P, Parker KL, Vassalli J-D (2005) Gene expression during sex determination reveals a robust female genetic program at the onset of ovarian development. Dev Biol 287:361-377.

Newbould S (2018) Classroom contract. English Teaching Forum 56:37-39.

Nixon R (2011) 10 things every man should know about a woman's brain. livescience.com. Available at: https://www.livescience.com/14421-human-brain-genderdifferences.html.
Nordstrom C, Bartels L, Bucy J (2009) Predicting and curbing classroom incivility in higher education. Coll Stud J 43:74+.

O'Connor C, Joffe H (2014) Gender on the brain: A case study of science communication in the new media environment PLoS One 9:e110830-15.

Pavlova MA (2017) Sex and gender affect the social brain: Beyond simplicity. J Neurosci Res 95:235-250.

Penn Medicine (2013, December 2) Brain connectivity study reveals striking differences between men and women [Press release]. https://www.pennmedicine.org/news/newsreleases/2013/december/brain-connectivity-study-revea.

Phoenix CH, Goy RW, Gerall AA, Young WC (1959) Organizing action of prenatally administered testosterone proprionate on the tissues mediating mating behavior in the female Guinea Pig. Endocrinology 65:369-382.

Prendergast BJ, Onishi KG, Zucker I (2014) Female mice liberated for inclusion in neuroscience and biomedical research. Neurosci Biobehav Rev 40:1-5.

Puts D (2016) Human sexual selection. Curr Opin Psychol 7:2832.

Reis E (2019) Did bioethics matter? A history of autonomy, consent, and intersex genital surgery. Med Law Rev 27:658674.

Rey R, Josso N, Racine C (n.d.) Sexual Differentiation [Updated 2020 May 27]. In: Feingold KR, Anawalt B, Boyce A, et al., editors. Endotext [Internet]. South Dartmouth (MA): MDText.com, Inc.; 2000-

Rippon G (2020) The gendered brain: The new neuroscience that shatters the myth of the female brain. London, England: Vintage.

Rippon G, Jordan-Young R, Kaiser A, Fine C (2014) Recommendations for sex/gender neuroimaging research: Key principles and implications for research design, analysis, and interpretation. Front Hum Neurosci 8 Available at: http://journal.frontiersin.org/article/10.3389/fnhum.2014.0065 O/abstract.

Rippon G, Eliot L, Genon S, Joel D (2021) How hype and hyperbole distort the neuroscience of sex differences. PLoS Biol 19(5): e3001253.

Risman BJ, Davis G (2013) From sex roles to gender structure. Curr Sociol 61:733-755.

Roughgarden J (2013) Evolution's rainbow: Diversity, gender, and sexuality in nature and people, Tenth anniversary edition. Berkeley Los Angeles London: University of California Press.

Sanchis-Segura C, Becker JB (2016) Why we should consider sex (and study sex differences) in addiction research: Importance of sex differences. Addict Biol 21:995-1006.

Schmitt DP, Long AE, McPhearson A, O'Brien K, Remmert B, Shah SH (2017) Personality and gender differences in global perspective. Int J Psychol 52:45-56.

Schneiberg $E$ (2021) These are the states attempting to pass anti-trans health care bills. Human Rights Campaign. Available at:_https://www.hrc.org/news/these-are-the-statesattempting-to-pass-anti-trans-health-care-bills.

Schulz KM, Molenda-Figueira HA, Sisk CL (2009) Back to the future: The organizational-activational hypothesis adapted to puberty and adolescence. Horm Behav 55:597-604.

Servedio MR, Boughman JW (2017) The role of sexual selection in local adaptation and speciation. Annu Rev Ecol Evol Syst 48:85-109.

Seydel C (2021) The missing sex. Nat Biotechnol 39:260-265.

Shansky RM (2019) Are hormones a "female problem" for animal research? Science 364:825-826.

Shansky RM, Woolley CS (2016) Considering sex as a biological variable will be valuable for neuroscience research. J Neurosci 36:11817-11822.

Shipman P (2015) Taking the long view on sexism in science. 
Am Sci 103:392.

Spencer D, Pasterski V, Neufeld SAS, Glover V, O'Connor TG, Hindmarsh PC, Hughes IA, Acerini CL, Hines M (2021) Prenatal androgen exposure and children's gender-typed behavior and toy and playmate preferences. Horm Behav 127:104889.

Springer KW, Mager Stellman J, Jordan-Young RM (2012) Beyond a catalogue of differences: A theoretical frame and good practice guidelines for researching sex/gender in human health. Soc Sci Med 74:1817-1824.

Summers L (2005) Full transcript: President Summers' remarks at the National Bureau of Economic Research. Available at: https://www.thecrimson.com/article/2005/2/18/full-transcriptpresident-summers-remarks-at/

Walia R, Singla M, Vaiphei K, Kumar S, Bhansali A (2018) Disorders of sex development: A study of 194 cases. Endocr Connect 7:364-371.

Wei D, Talwar V, Lin D (2021) Neural circuits of social behaviors: Innate yet flexible. Neuron 109:1600-1620.

Wentling T (2015) Trans* disruptions: Pedagogical practices and pronoun recognition. Transgender Stud Q 2:469-476.

West C, Zimmerman DH (1987) Doing gender. Gender Soc 1:125-151.

Wiggins GP, McTighe J (2005) Understanding by design, Expanded 2nd ed. Alexandria, VA: Association for Supervision and Curriculum Development.

Will TR, Proaño SB, Thomas AM, Kunz LM, Thompson KC, Ginnari LA, Jones CH, Lucas S-C, Reavis EM, Dorris DM, Meitzen J (2017) Problems and progress regarding sex bias and omission in neuroscience research. eNeuro 4:ENEURO.0278-17.2017

Wolpe PR (2004) Ethics and social policy in research on the neuroscience of human sexuality. Nat Neurosci 7:1031-1033.

Wood W, Eagly AH (2002) A cross-cultural analysis of the behavior of women and men: Implications for the origins of sex differences. Psychol Bull 128(5), 699-727.
Wood W, Eagly AH (2015) Two traditions of research on gender identity. Sex Roles 73:461-473.

Wood RI, Stanton SJ (2012) Testosterone and sport: current perspectives. Horm Behav 61(1), 147-155.

Young RM, Balaban E (2006) Psychoneuroindoctrinology. Nature 443:634-634.

Zilkha N, Scott N, Kimchi T (2017) Sexual dimorphism of parental care: From genes to behavior. Annu Rev Neurosci 40:273-305

Zucker I, Prendergast BJ (2020) Sex differences in pharmacokinetics predict adverse drug reactions in women. Biol Sex Differ 11:32.

Received March, \#\#, 2021; revised Month, \#\#, 2021; accepted Month, \#\#, 2021.

Acknowledgements: We thank the organizers of the FUN Summer 2021 Virtual Meeting for organizing an equity-minded program that included this topic. Thanks to Mary Harrington for hosting the Meeting Roundtable on teaching about race and gender in Neuroscience and for helpful initial conversations about framing this manuscript, and to other roundtable participants for sharing their perspectives during the meeting. Thanks to Clint Neil for helpful conversations with ECL as she first designed her course on this topic, and for the New College Feminist Fridays series for feedback on earlier forms of this resource. Thanks to Madhvi Venkatesh \& members of the Harvard Medical School Curriculum Fellows Program for helpful conversations with TT about her course on this topic. Thanks to reviewers for constructive feedback on the manuscript. Finally, we thank all of our students, past and present, who have explored this topic with us in our courses and inspired us to grow in our teaching practice.

Address correspondence to: Dr. Kathleen Casto, Division of Social Sciences, New College of Florida; Email: kcasto@ncf.edu

Copyright @ 2021 Faculty for Undergraduate Neuroscience www.funjournal.org 